\title{
Formation of communicative culture of future IT-specialists
}

\author{
Shchehlova A.* \\ National university of food technologies, Kyiv, Ukraine \\ Received: $12.06 .2018 \quad$ Accepted: 14.10 .2018
}

\begin{abstract}
Communication is a way of carrying out professional activities and implementation of its social goals through communicative culture. Culture of communication within professional environment is formed by one's own communicative culture. The need for enhancing future specialists' culture of communication is becoming more relevant and contributes to the emergence of higher requirements for professional communicative culture formation as a weighty prerequisite for professional competence. High level of communicative culture will help to establish effective versatile professional communication with colleagues or partners based on ethics and principles of mutual respect, support, justice and objectivity. Communicative culture of a high level makes it possible further professional growth and career promotion for those employees, whose professional activity requires constant interaction on the "man-man" pattern. So, the important task of modern higher education is to search for effective means to form communicative culture of future specialists in the field of information technologies and telecommunications. The article reveals the essence of communicative culture and defines features of its structural components; a theoretical analysis of the factors influencing individual communicative culture is presented; influence of modern information technologies and globalization on the formation of communicative culture in the process of professional training of future IT specialists is examined.
\end{abstract}

Key words: communicative culture; professional communication; informatization; communicative competence; globalization processes.

\section{Формування комунікативної культури майбутніх ІT-спеціалістів щеглова А. 0.}

Національний університет харчових технологій, Київ, Україна

\begin{abstract}
Анотація. Спілкування виступає як спосіб здійснення професійної діяльності та реалізації його соціальних цілей завдяки комунікативній культурі. Власною комунікативною культурою спеціаліст формує культуру спілкування свого профресійного оточення. Необхідність підвищення культури спілкування майбутніх фахівців наразі набуває все більшої актуальності та спричиняє появу більш високих вимог до формування профресійної комунікативної культури як вагомої передумови професійної компетентності. Високий рівень ссрормованості комунікативної культури сприятиме налагодженню ефрективного різнобічного професійного спілкування 3 колегами чи партнерами на підставі знань про етику спілкування та грунтуючись на принципах об'єктивності, підтримки, взаємоповаги та справедливості. Власне сформована комунікативна культура робить можливим подальше професійне зростання та самореалізацію спеціаліста, профресійна діяльність якого потребує постійної взаємодії за паттерном «людина-людина». Отже, важливим завданням сучасної профресійної освіти $\epsilon$ пошук ефеективних засобів формування комунікативної культури майбутніх спеціалістів сффери інформаційних технологій та телекомунікацій. У статті розкривається сутність комунікативної культури та особливості її структурних компонентів; здійснюється теоретичний аналіз факторів впливу на комунікативну культуру особистості; розглядається специфіка впливу сучасних інформаційних технологій та глобалізації на формування комунікативної культури в процесі професійної підготовки майбутніх IT фрахівців .
\end{abstract}

Ключові слова: комунікативна культура; професійне спілкування; інформатизація; комунікативна компетентність; глобалізаційні процеси.

Corresponding Author: Shchehlova Alla Oleksandrivna, e-mail: alla2704@i.ua, Tel. +38(097) 297-35-79. National university of food technologies, Volodymyrska str, 68, Kyiv, Ukraine, 01033

Biдnовідальний автор: Щеглова Алла Олександрівна, e-mail: alla2704@i.ua, Tel. +38(097) 297-35-79.

Національний університет харчових технологій, вул. Володимирська, 68, м. Київ, Україна, 01033. 


\title{
Формирование коммуникативной культуры будущих IT-специалистов
}

\author{
Щеглова А. А.
}

Национальный университет пищевых технологий, Киев, Украина

\begin{abstract}
Аннотация. Общение выступает как способ осуществления профессиональной деятельности и реализации его социальных целей благодаря коммуникативной культуре. Собственной коммуникативной культурой специалист формирует культуру общения своего профессионального окружения. Необходимость повышения культуры общения будущих специалистов становится все более актуальным и способствует появлению более высоких требований к формированию профессиональной коммуникативной культуры как весомой предпосылки профессиональной компетентности. Высокий уровень сформированности коммуникативной культуры будет способствовать налаживанию эффективного разностороннего профессионального общения с коллегами или партнерами на основании знаний об этике общения и основываясь на принципах взаимоуважения, поддержки, справедливости и объективности. Сформированная коммуникативная культура делает возможным дальнейший профессиональный рост и самореализацию специалиста, профессиональная деятельность которого требует постоянного взаимодействия по паттерну «человекчеловек». Итак, важной задачей современного профессионального образования является поиск эфффективных средств формирования коммуникативной культуры будущих специалистов сферы информационных технологий и телекоммуникаций. В статье раскрывается сущность коммуникативной культуры и особенности ее структурных компонентов; осуществляется теоретический анализ факторов влияния на коммуникативную культуру личности; рассматривается специфика влияния современных информационных технологий и глобализации на формирование коммуникативной культуры в процессе профессиональной подготовки будущих IT-специалистов.
\end{abstract}

Ключевые слова: коммуникативная культура; профрессиональное общение; информатизация; коммуникативная компетентность; глобализационные процессы.

\section{Bcmyn}

В умовах інформатизації суспільства та нових тенденцій глобалізаційних процесів майбутні спеціалісти сфрери телекомунікацій та інформації стають частиною складної мережі зв'язків, в основі яких лежить крос-культурна комунікація. Незважаючи на превалююче становище в даній галузі паттерна «людина-машина», професійне спілкування займає значне місце в повсякденній діяльності майбутнього IT-спеціаліста. Науково-технічний прогрес, відкритість кордонів та розвиток технологічних можливостей дають можливість розвивати новий рівень комунікативної культури. Дослідження аспектів впливу інформаційних технологій на формування комунікативної культури в рамках професійної комунікативної компетентності представляє собою великий практичний інтерес в контексті діалогу цивілізацій (глобальний рівень) та країн (інтернаціональний рівень). Професійна освіта та комунікативна культура $є$ абсолютно взаємозалежними категоріями, адже ефективна взаємодія з іншими людьми стає фундаментом для побудови робочого колективу як первинної ланки виробничого процесу, а також основою для розвитку партнерських відносин між компаніями, вмінням вибудовувати конструктивний діалог з менеджментом та орієнтації на професійний ріст та просування.

Зважаючи на вище викладене, проблема впливу інформаційних технологій на формування комунікативної культури майбутніх фахівців високотехнологічної сфери характеризується актуальністю та необхідністю її вирішення.

Meта роботи: виявлення особливостей формування комунікативної культури майбутніх ITспеціалістів.

\section{II Матеріал і методи дослідження}

Багатоаспектність процесу формування профресійної комунікативної культури знайшла своє відображення в багатьох наукових працях. Комунікативну культуру як міждисциплінарну категорію досліджували М. Василик, Л. Землянова, Г. Почепцов. Праці С. Ольховецького, Л. Петровської, Г. Сагач підіймають питання формування комунікативної культури особистості, а саме розглядається комунікативна взаємодія та комунікативні вміння. Визначення теоретичних засад впливу глобального інформаційного середовища на формування комунікативної культури є провідним завданням даного дослідження. 
Визначальною рисою будь-якої культури є подібність того, якою є інформація про оточуючий світ, який інтерпретується. Наприклад, два суб'єкта спілкування, які поділяють етнічні, релігійні чи політичні ознаки, як правило, матимуть співвіднесені моделі світосприйняття, що полегшить спілкування. Аналіз поняття комунікація розкривається через поняття передачі певного типу повідомлення, а передача в свою чергу імплікує процес взаємодії, яка відбувається в діяльності, підтриманні особистих та ділових стосунків [1, с. 258].

Об'єктивне значення комунікативної культури полягає у її особливостях, а саме упорядкованості, нормативності, системності, які проявляються у комунікативних вміннях майбутнього фахівця, та не обмежуються при цьому лише мовленнєвими вміннями, а й маються у своїй складній підсистемі вміння взаємодіяти, сприймати протилежну сторону. Отже, комунікативна культура є невід'ємною частиною загальної концепції культури, та охоплює систему цінностей та якостей особистості - мислення, культуру мовлення, культуру мови тіла (жести, рухи, емоційний спектр тощо).

Комунікативна культура виражається в умінні встановлювати особистісно-орієнтовані взаємовідносини між суб'єктами, тому її зміст можна зобразити умовно у такій ієрархічній послідовності як комунікативні установки, теоретичні знання про комунікативну культуру та закономірності й етику спілкування, комунікативні уміння. Формуючі елементи комунікативної культури наведено на рис.1.

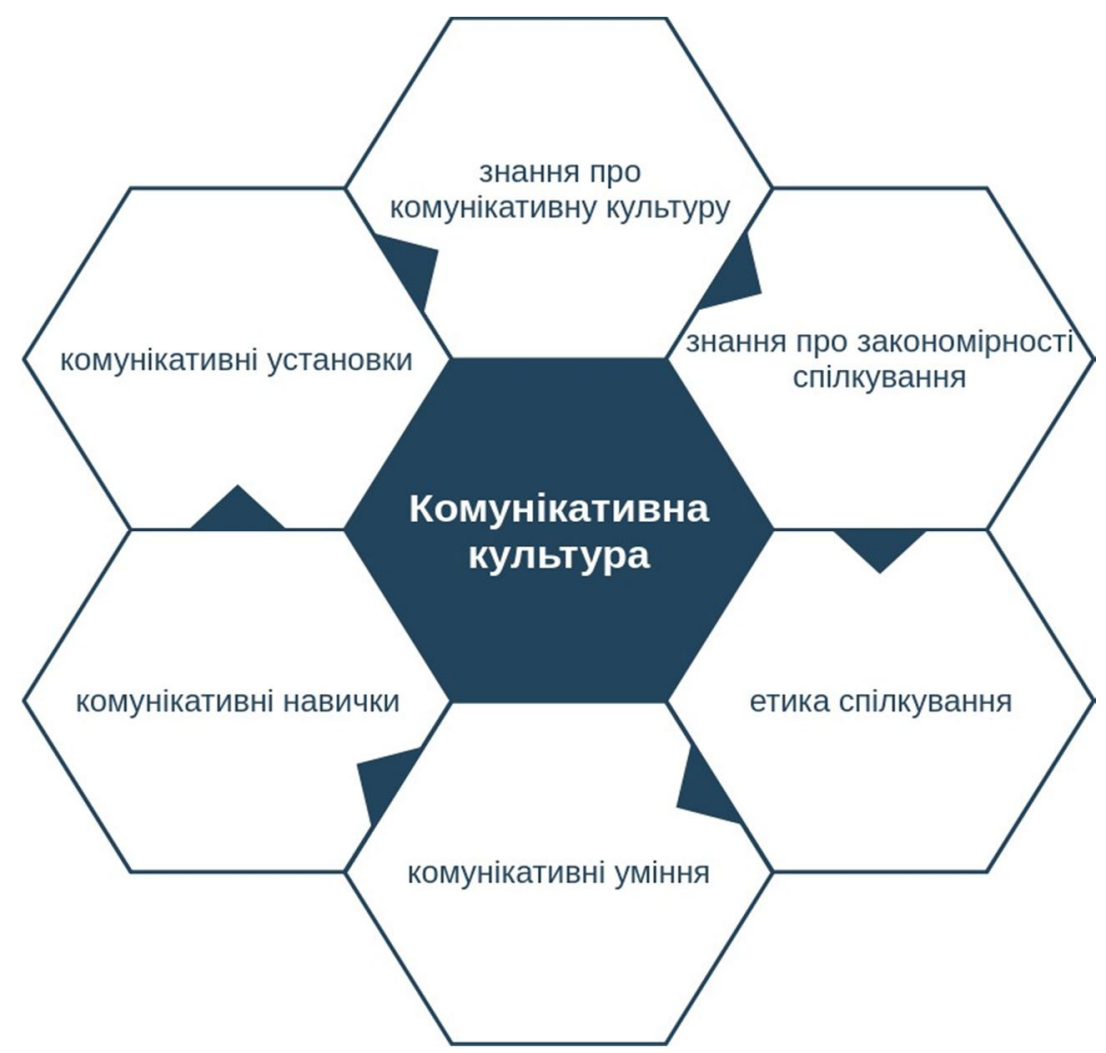

Рис. 1 Структурні компоненти комунікативної культури

Комунікативні установки, які $€$ психологічною основою комунікативних якостей особистості, забезпечують її готовність до побудови комунікативної взаємодії у визначеному стилі, поєднуючи в систему елементи ситуації спілкування з минулим досвідом людини, ініціюючи при цьому певний хід міркування та дій.

Теоретичні знання про комунікативну культуру та етику спілкування - набір власного досвіду про раціональність, правильність, етичність вчинків та дій у визначеній ситуації.

Комунікативні вміння являють собою відображення комплексу автоматизованих свідомих дій на основі теоретичних знань та практичної підготовки з метою досягнення поставлених цілей.

Дана структура комунікативної культури $€$ динамічною, адже кожний з рівнів $€$ залежним, характеризується гнучкістю, саморегуляцією, але при цьому перебуває у тісній взаємодії, що зумовлено розвитком особистості майбутнього спеціаліста. 
Комунікативній культурі відведено провідне місце в професійному становищі особистості. А умови сучасного інформаційного середовища дають можливість виділити комунікативну культуру на рівень діяльнісного підходу з мультифункціональним характером. При формуванні структурних рівнів комунікативної культури варто відзначити такі варіативні фактори об'єктивного та суб'єктивного впливу, як загальнолюдські характеристики, особистісні орієнтири та історично обумовлені фактори, які визначають особливості інтеракції, перцепції та власне комунікації [4, с. 49].

Фактори формування комунікативної культури можна також поділити на зовнішні та внутрішні, тобто ті, які є результатом соціальної взаємодії з оточуючим світом, та ті, що пройшли крізь особистісну призму, і є взаємозалежними та взаємодоповнюючими один одного. Проте основою формування комунікативної культури є досвід спілкування на міжособистісному рівні та макрогрупі. Отже, провідною сутнісною характеристикою сучасного фрахівця та одним із важливих показників рівня фрахової підготовки $€$ саме комунікативна культура. 3 метою реалізації власного комунікативного потенціалу майбутніх спеціалістів важливо правильно організувати навчально-виховний процес, позанавчальний час, відповідну інтеракцію начального закладу з іншими соціальними та навчальними інститутами.

\section{III Результати}

Досліджуючи проблему формування комунікативної культури, необхідно акцентувати увагу на внутрішні фактори: важливість їі гуманістичної спрямованості, при якій інша людина сприймається і визначається як найвища цінність; критерії ефективності взаємодії - наприклад, придатність підібраних засобів для досягнення бажаного результату, відповідність витрати часу, сил і засобів цінностям кінцевого результату, мінімізація ризику несподіваних негативних наслідків [3]. Проте важливого значення наразі набувають і зовнішні фактори, які впливають на формування комунікативної культури, серед яких на макрорівні глобальне інформаційне середовище. Майбутні IT-спеціалісти матимуть можливість комунікації на інтернаціональній арені, особливо якщо говорити про роль проектних менеджерів, технічних директорів, керівників проектів, чиє безпосереднє завдання - комунікація 3 головним офрісом, замовником, клієнтом чи потенційним партнером (рис. 2). Найчастіше така комунікація відбувається опосередковано, тобто за допомогою спеціального програмного забезпечення та технологій віддаленого спілкування, проте персональні зустрічі також не $є$ винятком. Відомо, що міжкультурний підхід в бізнесі завжди був актуальним, але з настанням епохи відкритих кордонів та вільного доступу до інформації, рівень нагальності його імплементації в життя збільшився. Кожна культура має правила, які їі члени вважають само собою зрозумілими. Мало хто усвідомлює свою власну упередженість, тому що культурна включеність починається в дуже ранньому віці. I хоча культурним знанням, правилам, цінностям навчаються, більшість поглинається підсвідомо.

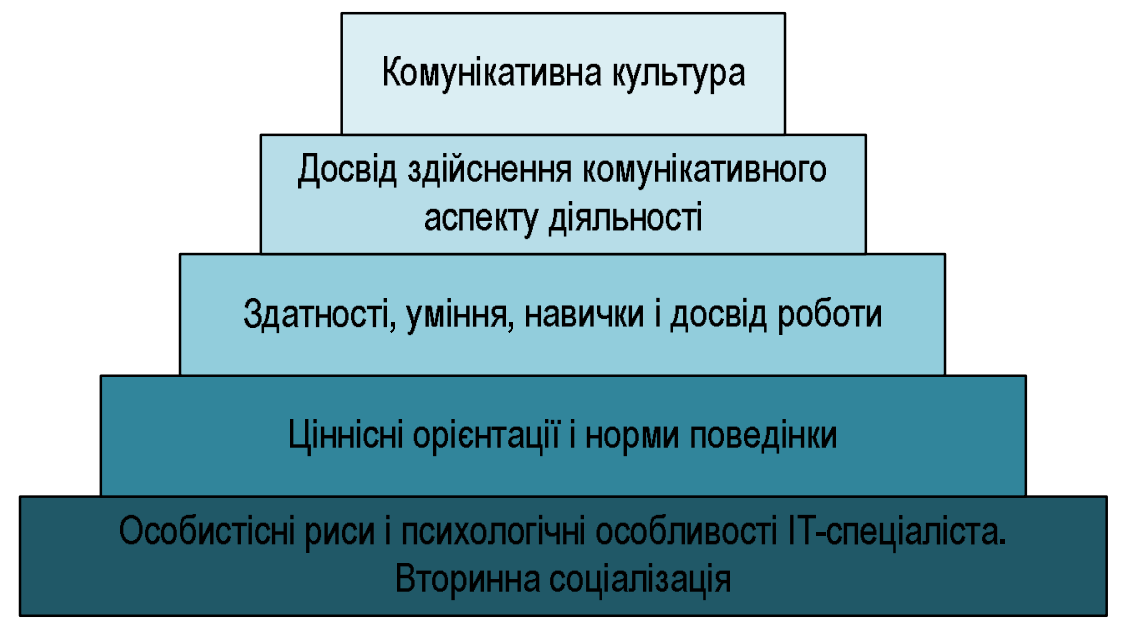

Рис. 2. Структура комунікативної компетентності IT-спеціаліста

Кожний аспект глобального спілкування впливає на культурні відмінності. Навіть вибір середовища, який використовується для спілкування, може мати культурний натяк. Наприклад, промислово розвинені країни, такі як США, Канада, Велика Британія та Німеччина, сильно залежать від 
електронних технологій та підкреслюють письмові повідомлення про усне або особисте спілкування. Японія ж, яка має доступ до найсучасніших технологій, все більше спирається на особисті комунікації, ніж на письмовому рівні [5]. Визначальним чинником переваги може бути не ступінь індустріалізації, а скоріше, чи країна потрапляє у висококонфліктну або низькоконфрліктну культуру. У деяких культурах особисті зобов'язання та неформальні угоди $€$ набагато більш обов'язковими, ніж будь-який формальний контракт. В інших, ретельно сформулювані юридичні документи розглядаються як першочергові. Висока контекстна культура (середземноморська, слов'янська, центральноєвропейська, латиноамериканська, африканська, арабська, азійська, американо-індійська) залишає більшу частину повідомлення невизначеною - це слід розуміти через контекст, невербальні сигнали та інтерпретацію того, що насправді сказано. Навпаки, низькоконфліктні культури (більшість німецьких та англомовних країн) очікують, що повідомлення будуть явними та конкретними. Перші шукають сенсу і розуміння в тому, що не сказано - в мові тіла, паузах, у відносинах та співпереживанні. Останні роблять акцент на надсиланні та одержанні точних повідомлень безпосередньо, а також відзначаються точністю, якщо вони говорять особисто чи у письмовій формі. У міжнародних ділових відносинах, емоції та раціональний сенс теж відіграють певну роль. Який з цих двох факторів, домінує залежить від того, чи $є$ інша сторона афективна, тобто чи легко виявляє емоції, або емоційно нейтральна у своєму підході. Члени нейтральних культур не показують свої почуття, тримають їх під ретельним контролем. У афективних культурах люди ж, навпаки, відкриті, усміхнені, здатні проявляти навіть більш емоційні стани під час переговорів. У сучасній глобальній бізнес-спільноті немає єдиного оптимального підходу до спілкування один з одним. Ключем до міжкультурного успіху є розвиток розуміння та глибокої поваги до відмінностей комунікативної культури.

Темпи, з якими наші гаджети стають все більш потужними, свідчать про розвиток, і недавні стрибки в технології протягом останніх десятиліть кардинально змінили підхід до спілкування один 3 одним не лише в приватному житті, а й в професійному. Наразі ми все більше і більше віддаємо перевагу швидким та зручним можливостям, в основі яких лежить Інтернет, ніж обираємо особисту зустріч. Мобільні телефони та інші мобільні пристрої, такі як планшети, посилюють вплив Інтернету. Вони дозволяють спілкуватися з сотнями або навіть тисячами контактів на безлічі сервісів і платформ через кілька дотиків на екрані. Електронна пошта представляє собою фрормат обміну інформацією, при цьому дозволяючи одночасно надсилати одне і те ж повідомлення десяткам людей, і це дозволяє супроводжувати слова з зображеннями, посиланнями та іншими файлами. Це зробило спілкування більш різноманітним та гнучким, надаючи низку нових способів поширення інформації, а також збереження всіх даних на єдиному сервері компанії, тобто працівник завжди може ознайомитися 3 даними, які його цікавлять без ймовірності втратити щось суттєве.

\section{IV Обговорення}

У зв'язку з появою та широким використанням нових інформаційних технологій з'являється необхідність у зміні деяких підходів до процесу спілкування та комунікативної культури. Це не означає повне перефрорматування стандартів, базові моменти залишаються, але вони адаптуються до нових реалій сьогодення. Виникає сукупність правил прийнятної поведінки в Інтернеті - нетикет, тобто основи комунікативного етикету при використанні онлайн-ресурсів в онлайн-соціальному середовищі. Більшість користувачів Інтернету автоматично застосовують таку ж відповідальність в контексті поведінки в Інтернеті, як і в будь-якому іншому середовищі. Це означає, що для спілкування в Інтернеті, наприклад, електронною поштою, форумами, блогами та сайтами соціальних мереж, важливо використовувати нетикет, оскільки спілкування в Інтернеті є невербальним, тобто він не дозволяє кожній людині бачити міміку, мову тіла або чути інтонацію. Через це повідомлення часто можна неправильно тлумачити [2, c. 92]. За допомогою нетикету спілкування стає чіткішим. Особливо в діловому та кар'єрному напрямку інтернет-комунікаційний етикет має використовуватися для забезпечення правильності написання, перевірки граматики та пунктуації, адже це впливає на імідж власне працівника та компанії, яку він представляє. Нетикет також включає в себе використання додаткових символів, щоб пояснити емоцію, яка супроводжує текстову інформацію. Нетикет допомагає підтримувати та встановлювати позитивні онлайн-стосунки, а також розвивати позитивну онлайн-репутацію та позиціонувати себе в бізнессередовищі. 


\section{V Висновки}

Проблема впливу нових технологій на фрормування комунікативної культури майбутніх спеціалістів у сфері інформації та телекомунікації має велике значення для успішного навальновиховного процесу у закладі вищої освіти та модифікації його змістового наповнення. Виникає потреба розроблення інноваційних технологій формування комунікативної культури студентської молоді, що позначається на культурі спілкування студентів і потребує всебічного та детального вивчення у перспективі. Структурні компоненти комунікативної культури, закладаючись у особистості майбутнього IT-фахівця в ході професійної діяльності та спілкування, динамічно розвиваються при переході на нові рівні розвитку. Тому слід значно більше уваги приділяти комунікативній спрямованості при навчанні, адже інтенції комунікантів $€$ конструктивним засобом вирішення багатьох актуальних проблем.

\section{Бібліографічні посилання}

[1] Атаманчук Ю.М. Концепції інформатизації вищої освіти: вітчизняний і зарубіжний погляди / Вісник Житомирського державного університету. Педагогічні науки. 2015. Випуск 1(79). С. 59-64.

[2] Галацин К.О. Моделювання процесу формування комунікативної культури майбутніх інженерів / Вісн. Харк. держ. акад. культури : зб. наук. пр. Вип. 41. Х. : ХДАК, 2013. С. 257-261.

[3] Денисенко Т.О., Грешнєв О. Є. Інформаційні технології в освіті / Інформаційна освіта та професійно- комунікативні технології XXI століття: матеріали VI міжнар. наук.практ. конф. (Одеса, 12-14 вересня 2013 р.). Одеса, 2013. С.59-62.

[4] Кулакова О.М. Компонента культури в мовній комунікації інсормаційного суспільства / Науковий вісник Харківського нац. пед. ун-ту ім. Г. С. Сковороди. Х., 2009. Вип. 32. С. 90-99.

[5] Мельник І.Ю. Комунікативне середовище в університетській освіті / Інформаційна освіта та професійно- комунікативні технології XXI століття: матеріали VI міжнар. наук.-практ. конф. (Одеса, 12-14 вересня 2013 р.). Одеса, 2013. С.226230.

[6] Руденко Л.А. Формирование коммуникативной культуры будущих специалистов в контексте инновационной образовательной деятельности / Отечественная и зарубежная педагогика. 2014. № 3 (18). С. 114-122.

[7] Садовская В.С., Ремизов В. А. Основы коммуникативной культуры ; общ. ред. Ремизова В. А. М. : Гуманит. изд. центр ВЛАДОС, 2011. $206 \mathrm{C}$.

[8] Смирнова И.В, Смирнова О.Д. Культура коммуникационной деятельности: понятие, структура и функции / Научный вестник Дальневост. Госуд. ун-та. 2008. №5-6. С.46-57.

[9] Сисоєва С.О., Баловсяк Н. В. Інформаційна компетентність фахівця: теорія та практика формування : навч.-метод. посібник. Чернівці : Технодрук, 2006. 208 с.

[10] Філіпова Л.Я. Концепції інформаційної парадигми соціальної комунікації / Інформаційна освіта та професійнокомунікативні технології XXI століття: матеріали VI міжнар. наук.-практ. конф. (Одеса, 12-14 вересня 2013 р.). Одеса, 2013. C.14-18.

[11] Lasen M. Education and career pathways in Information Communication Technology: What are schoolgirls saying? I Computers \& Education. 2010.54(4). C1117-1126. URL: https://doi.org/10.1016/j.compedu.2009.10.018. (дата звернення 10.06.2018)

[12] Louis V. Compétence communicative et saviors culturels en didactique des langues étrangeres / Université de Liege. 2006. P. $50-63$.

[13] Kylouskova N. La compétence de communication / Brno, 2001. P. 33-38.

[14] Perrenoud Ph. Compétences, langage et communication / Université de Geneve, 2000. P. $42-49$.

[15] Trager G., Hall E. Culture and Communication: A Model and an Analysis // Explorations and Communication. 1994. № 3. P. $32-38$.

\section{References}

[1] Atamanchuk, Yu.M. (2015), Koncepcii informatyzatsii vyshhoi osvity: vitchyznianyi i zarubizhnyi pohliady, Journal of Zhytomyr State University. Pedagogical Sciences, Iss. 1(79), 59-64. [in Ukrainian]

[2] Halatsyn, K.O. (2013). Modeliuvannia protsesu formuvannia komunikatyvnoi kultury maibutnikh inzheneriv, Journal of Kharkiv State academy of Culture, Iss. 41, 257-261.[in Ukrainian]

[3] Denysenko, T.O., Hreshniev, O.Ye. (2013). Informatsiini tekhnolohii v osviti, Informational education and professional communication technologies of XXI century: materails of VI intermational scientific conference, Odesa, September 12-14, pp. 59-62. [in Ukrainian]

[4] Kulakova, O.M. (2009), Komponenta kultury v movnii komunikatsii informatsiinoho suspilstva. Journal of Kharkiv Nat. Ped. Univ. after H. S. Skovoroda, Kharkiv, Iss. 32, 90-99. [in Ukrainian]

[5] Melnyk, I.Yu. (2013). Komunikatyvne seredovyshche $v$ universytetskii osviti, Informational education and professional communication technologies of XXI century: materails of VI intermational scientific conference, Odesa, September 12-14, pp. 226-230. [in Ukrainian] 
[6] Rudenko, L.A. (2014). Formirovanie kommunikativnoi kultury budushchikh spetsialistov $v$ kontekste innovatsionnoi obrazovatelnoi deiatelnosti. Domestic and Foreign Pedagogy Journal, № 3 (18), 114-122. [in Russian]

[7] Sadovskaya, V.S. (2011). Osnovy kommunikativnoi kultury. Moscow: VLaDOS, 206. [in Russian]

[8] Smirnova, I.V., Smirnova, O.D. (2008). Kultura kommunikatsionnoi deiatelnosti: poniatie, struktura i funktsii. Journal of Dalnevost. State University, № 5-6, 46-57. [in Russian]

[9] Sysoieva, S.O. (2006). Informatsiina kompetentnist fakhivtsia: teoriia ta praktyka formuvannia. Chernivtsi: Tekhnodruk, 208. [in Ukrainian]

[10 Filipova, L.Ya. (2013). Kontsepcii informatsiinoi paradyhmy sotsialnoi komunikatsii, Informational education and professional communication technologies of XXI century: materails of VI intermational scientific conference, Odesa, September 12-14, pp. 14-18. [in Ukrainian]

[11] Lasen, M. (2010). Education and career pathways in Information Communication Technology: What are schoolgirls saying? Computers \& Education, 54(4), 1117-1126. doi: https://doi.org/10.1016/j.compedu.2009.10.018.

[12] Kylouskova, N. (2001). La compétence de communication. Brno, pp. 33-38. [in French]

[13] Louis, V. (2006). Compétence communicative et saviors culturels en didactique des langues étrangeres. Université de Liege, pp. 50-63. [in French]

[14] Perrenoud, Ph. (2000). Compétences, langage et communication, Université de Geneve, pp. 42-49. [in French]

[15] Trager, G., Hall, E., (1994). Culture and Communication: A Model and an Analysis. Explorations and Communication, Iss. 3 , 32-38. [in English]

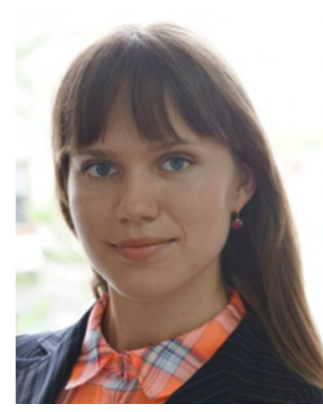

Щеглова Алла Олександрівна, викладач кафедри ділової іноземної мови та міжнародної комунікації, Національний університет харчових технологій, вул. Володимирська, 68, м. Київ, Україна, 01033. Тел. +38(097) 297-35-79. E-mail: alla2704@i.ua

Shchehlova Alla Oleksandrivna,

Teacher of Department of Business Foreign Language and International Communication, National University of Food Technologies, vul. Volodymyrska, 68, Kyiv, Ukraine, 01033.

Тел. +38(097) 297-35-79. E-mail: alla2704@i.ua

Researcher ID: U-2605-2018

\section{Citation (APA):}

Shchehlova, A. (2018). Formation of communicative culture of future IT-specialists. Engineering and Educational Technologies, 6 (3), 45-51. doi: https://doi.org/10.30929/2307-9770.2018.06.03.05 (in Ukrainian)

\section{Цитування (ДСТУ 8302:2015):}

Щеглова А. О. Формування комунікативної культури майбутніх ІТ-спеціалістів / Інженерні та освітні технології. 2018. Т. 6. № 3. C. 45-51. doi: https://doi.org/10.30929/2307-9770.2018.06.03.05

Обсяг статmi: 7 сторінок, 0,805 умовних друк. аркушів. 